\title{
PENGARUH PENGETAHUAN PERPAJAKAN DAN PERSEPSI KEADILAN TERHADAP TINGKAT KEPATUHAN WAJIB PAJAK MELALUI KEPERCAYAAN
}

\author{
Ari Yulianti \\ Asep Kurniawan \\ Indah Umiyati \\ Program Studi Akuntansi STIE Sutaatmadja \\ indahumiyati@stiesa.ac.id
}

\begin{abstract}
This study aims to determine the effect of tax knowledge and perception of justice to compliance of taxpayer pp 46 year 2013 registered at tax office Subang and to determine the influence of knowledge taxation and perception of justice to compliance of taxpayer pp 46 year 2013 registered at tax office Subang through trust variables.

This research uses quantitative descriptive method by using primary data. Data collection technique is by questionnaire. The population in this study is all taxpayers entrepreneurs included into PP 46 year 2013 registered at Tax Office Subang, and samples in this study as many as 100 respondents. Hypothesis testing using Structural Equation Modeling (SEM) analysis.

The results of this study indicate that tax knowledge have an effect on taxpayer compliance, and perception of justice have an effect on taxpayer compliance, whereas trust does not mediate the influence of tax knowledge on compliance and perception of justice toward compliance.
\end{abstract}

Keywords: Tax Knowledge, Perception of Justice, Trust, Tax Compliance

\section{PENDAHULUAN}

Indonesia merupakan salah satu negara yang pendapatan utamanya berasal dari sektor perpajakan, penerimaan pajak di Indonesia menyumbang sekitar $70 \%$ dari seluruh penerimaan negara. Sehingga, pajak merupakan hal yang penting karena tanpa pajak sebagian besar kegiatan negara akan sulit untuk bisa berjalan dengan baik (Pajak.go.id). Setiap tahun (khususnya tahun 2013-2017) penerimaan pajak di Indonesia terus mengalami peningkatan, namun tidak dapat mencapai target yang telah ditentukan. Tidak tercapainya target tersebut menunjukan bahwa tingkat kepatuhan wajib pajak dalam hal membayar pajak di Indonesia masih rendah. Begitupun dengan tingkat kepatuhan Wajib Pajak dalam hal melaporkan pajaknya juga masih rendah, kisaran 60\%-70\% dan itupun masih didominasi oleh wajib pajak orang pribadi karyawan bukan wajib pajak pengusaha (Pajak.go.id).

Menteri keuangan Sri Mulyani mengungkapkan bahwa pemerintah saat ini gencar mengejar pajak dari mereka yang tidak patuh pajak (Merdeka.com). Bahkan saat ini pemerintah mulai melirik sektor swasta seperti Usaha Mikro, Kecil, dan Menengah (UMKM) yang dipastikan memiliki potensi besar bagi penerimaan pajak. Oleh karena itu, Peraturan Pemerintah No. 46 Tahun 2013 dibuat untuk mendorong penerimaan pajak dari 
sektor UMKM dengan tujuan untuk memudahkan para UMKM dalam melaksanakan kewajiban perpajakan (Imaniati, 2016). Namun demikian sampai saat ini porsi kontribusi penerimaan pajak dari UMKM ini masih relatif kecil (Pajak.go.id).

Berdasarkan catatan Dirjen Pajak, realisasi $\mathrm{PPh}$ final atau pajak UMKM tahun 2017 masih jauh dari target. Penerimaan pajak UMKM hanya terealisasi sebesar Rp106,33 triliun atau $68,08 \%$ dari target Rp156,18 triliun. Raihan ini menurun dibandingkan dengan capaian 2016 yang mencapai Rp117,68 triliun atau 80,77\% (Finansial.bisnis.com). Rendahnya penerimaan pajak UMKM juga terjadi di kabupaten Subang. Saat ini Kabupaten Subang memiliki sebanyak 22.000 (dua puluh dua ribu) UMKM yang terdaftar di DINAS KUMKM menurut data yang diambil per Mei 2017. Akan tetapi fakta menunjukan bahwa dari 22.000 UMKM hanya 2.136 atau kurang dari $10 \%$ yang melakukan pembayaran pajak menggunakan Peraturan Pemerintah No.46 tahun 2013 (stiesa.ac.id).

Berdasarkan penelitian yang dilakukan oleh Faizal at al (2017) di Malaysia ada beberapa faktor yang mempengaruhi kepatuhhan wajib pajak yaitu keadilan sebagai variabel bebas dan kepercayaan sebagai variabel intervening (perantara). Namun penelitian Faizal at al (2017) masih dalam tahap awal dengan tidak mendukung beberapa hipotesis karena respon yang minimal. Hal ini membuat peneliti tertarik untuk meneliti kembali pengaruh persepsi keadilan terhadap kepatuhan melalui kepercayaan di Indonesia khususnya di Kabupaten Subang, dengan menambah satu variabel bebas yaitu pengetahuan. Alasan peneliti menambah variabel pengetahuan sebagai variabel bebas yaitu karena pengetahuan merupakan salah satu variabel penting yang mempengaruhi kepatuhan. Perilaku wajib pajak didasarkan pada pandangan mereka terhadap pajak itu sendiri, kurangnya pengetahuan perpajakan cenderung menyebabkan rendahnya kesadaran wajib pajak dalam membayar pajak.

Telah banyak dilakukan penelitian terhadap pengaruh pengetahuan perpajakan terhadap kepatuhan diantaranya yaitu penelitian Saridane (2012); Nugroho (2016); Sudrajat \& Ompusunggu (2015); dan Zahra (2017). Namun peneliti menemukan adanya perbedaan hasil penelitian yang menyebutkan bahwa pengetahuan perpajakan memiliki hubungan positif yang signifikan terhadap kepatuhan wajib pajak, dengan penelitian Zahra (2017) yang menyebutkan bahwa pengetahuan pajak tidak berpengaruh terhadap kepatuhan wajib pajak, dan penelitian Saad (2012) yang menyebutkan bahwa pengetahuan pajak yang baik juga bisa memotivasi para pembayar pajak untuk menghindari membayar pajak.

Sehingga hal tersebut semakin membuat peneliti tertarik untuk melakukan penelitian mengenai pengaruh pengetahuan perpajakan dan persepsi keadilan terhadap tingkat kepatuhan wajib pajak. Penelitian berfokus pada Wajib Pajak yang dikenai PP 46 Tahun 2013 yang terdaftar di KPP Pratama Subang. Penelitian ini bertujuan untuk mengetahui pengaruh pengetahuan perpajakan dan persepsi keadilan terhadap tingkat kepatuhan Wajib Pajak PP 46 Tahun 2013 yang terdaftar di KPP Pratama Subang dan untuk mengetahui pengaruh pengetahuan perpajakan dan persepsi keadilan terhadap tingkat kepatuhan Wajib Pajak PP 46 Tahun 2013 melalui variabel kepercayaan.

Untuk itu hipotesis dalam penelitian ini adalah (1) Pengetahuan perpajakan berpengaruh positif terhadap perilaku kepatuhan pajak, (2) Persepsi keadilan pajak berpengaruh positif 
terhadap Kepatuhan Wajib Pajak, (3) Pengetahuan perpajakan berpengaruh positif terhadap perilaku kepatuhan pajak melalui kepercayaan, (4) Persepsi keadilan pajak berpengaruh positif terhadap Kepatuhan Wajib Pajak melalui Kepercayaan. Untuk menjawab hipotesis tersebut peneliti menggunakan analisis Structural Equation Modeling (SEM) dengan sampel sebanyak 100 responden.

Berdasarkan hasil dari penelitian sebelumnya menunjukkan bahwa persepsi keadilan dalam sistem perpajakan dan kepercayaan terhadap otoritas pajak memiliki hubungan signifikan positif (Faizal at al, 2017). Kemudian pengaruh pengetahuan pajak terhadap kepatuhan dibuktikan oleh penelitian sebelumnya bahwa pengetahuan perpajakan memiliki hubungan positif yang signifikan terhadap kepatuhan wajib pajak (Saridane, 2012; Nugroho, 2016; Sudrajat dan Ompusunggu, 2015). Penelitian ini merupakan terusan dari penelitian Faizal at al (2017) dengan menambahkan satu variabel bebas yaitu pengetahuan perpajakan.

\section{KERANGKA TEORITIS DAN HIPOTESIS}

Pajak adalah kontribusi wajib kepada negara untuk menyerahkan sebagian harta yang dimiliki wajib pajak dan dapat dipaksakan berdasarkan Undang-undang, tanpa adanya kontraprestasi atau tidak mendapat imbalan secara langsung dan digunakan semata-mata untuk kemakmuran rakyat. Salah satu pajak yang dipungut diindonesia adalah pajak penghasilan (PPh) yaitu pajak yang dikenakan kepada orang pribadi atau badan atas penghasilan yang diterima atau diperoleh dalam satu tahun pajak (Direktorat Jenderal Pajak). Pengasilan yang didapatkan oleh wajib pajak dapat dikenakan pajak bersifat final dan tidak final. Pajak final ini salah satunya adalah pajak yang dikenakan pada penghasilan dari usaha yang diterima atau diperoleh wajib pajak yang memiliki peredaran bruto tertentu.

Peraturan Pemerintah Nomor 46 Tahun 2013 yang merupakan kebijakan yang mengatur pajak penghasilan atas penghasilan dari usaha yang diterima atau diperoleh wajib pajak yang memiliki peredaran bruto tertentu diberlakukan pada 1 juli 2013 dengan tujuan agar memudahkan bagi wajib pajak dengan predaran bruto tertentu khususnya para pelaku usaha. Pelaku usaha di Kabupaten Subang sangat banyak hal ini dapat dilihat dari jumlah UMKM yang mencapai angka 22.000, tetapi penerimaan pajak PP No. 46 tahun 2013 masih sangatlah jauh dari target yang ditentukan. Padahal tarif pajak hanya sebesar $1 \%$ dari predaran bruto yang tidak melebihi Rp. 4,8 M pertahun. Dari 22.000 UMKM hanya sekitar 2.136 yang melakukan pembayaran pajak dengan menggunakan PP No. 46 tahun 2013. Rendahnya kepatuhan wajib pajak dapat dipengaruhi oleh beberapa faktor diantaranya pengetahuan perpajakan, persepsi keadilan dan kepercayaan.

Teori yang mendukung dalam penelitian ini adalah Theory of Planned Behavior. Dalam psikologi, Theory of Planned Behavior adalah teori tentang hubungan antara sikap dan perilaku. Teori ini dikembangkan oleh Icek Ajzen sebagai pengembangan dari teori aksi beralasan. Teori ini telah diterapkan pada studi tentang hubungan antara kepercayaan, sikap, dan perilaku di berbagai bidang seperti periklanan, hubungan masyarakat, kampanye periklanan dan perawatan kesehatan (Russell dan Cohn, 2012). Theory Of Planned Behavior menjelaskan bahwa perilaku seseorang dipengaruhi oleh sikap, yang meliputi kepercayaankepercayaan normatif atau keadaan lingkungan sekitar individu. Hal ini menunjukan bahwa keadaan sistem pajak yang adil dapat mempengaruhi wajib pajak dalam menentukan perilaku. Kemudian minat berperilaku dalam hal ini patuh di 
pengaruhi oleh kontrol perilaku (pengetahuan) dan norma subjektif (kepercayaan). Sehingga teori ini menjadi dasar dari pengaruh pengetahuan perpajakan, persepsi keadilan, dan kepercayaan terhadap kepatuhan.

Selanjutnya, atribusi merupakan salah satu proses pembentukan persepsi maupun perilaku. Teori atribusi mencoba menemukan apa yang menjadi penyebab seorang individu melakukan sebuah perilaku. Pada dasarnya, teori atribusi mengemukakan mengenai usaha ketika individu-individu mengamati perilaku untuk menentukan apakah perilaku tersebut ditimbulkan secara internal atau eksternal (Robbins dan Judge, 2008). Dalam teori atribusi pengetahuan dan kepercayaan merupakan faktor internal yang mempengaruhi perilaku termasuk perilaku kepatuhan. Kemudian keadilan merupakan faktor eksternal yang mempengaruhi perilaku, hasil dari persepsi keadilan yang akan mempengauhi perilaku tersebut. Sehingga pengaruh pengetahuan, persepsi keadilan, dan kepercayaan dalam penelitian ini terhadap kepatuhan didasarkan pada teori atribusi.

Kemudian pengaruh persepsi keadilan terhadap kepatuhan didasarkan pada teori keadilan. Dalam teori ini adil berarti seimbang dan tidak berat sebelah sehingga dalam pajakpun harus demikian. Pajak yang adil dimata wajib pajak akan menumbuhkan kepatuhan wajib pajak. Teori selanjutnya yang mendukung penelitian ini yaitu teori kepercayaan. Kepercayaan akan sistem perpajakan akan meningkatkan kepatuhan. Wajib pajak akan secara sukarela membayar pajak jika mereka percaya terhadap sistem hukum dan pemerintah. Teori kepercayaan ini menjelaskan bahwa kepercayaan seseorang dipengaruhi oleh beberapa faktor yaitu kemampuan, niat baik, dan intergitas. Kemampuan seseorang meliputi kemampuan dalam ilmu pengetahuan dan integritas dapat dilihat dari sudut keadilan. Oleh karena itu, teori ini menjelaskan bahwa pengetahuan dan keadilan merupakan faktor yang mempengaruhi kepercayaan. Sehingga pengetahuan dan keadilan dapat secara tidak langsung mempengaruhi kepatuhan melalui kepercayaan.

\section{Pengaruh Pengetahuan Perpajakan terhadap Kepatuhan Wajib Pajak}

Pengetahuan wajib pajak atas sistem perpajakan merupakan hal yang penting sebagai pedoman wajib pajak dalam melaksanakan hak dan kewajiban perpajakannya. Karena bagaimana mungkin wajib pajak akan patuh apabila mereka tidak mengetahui bagaimana peraturan perpajakan. Dalam penelitian Saridane (2012) Pengetahuan perpajakan secara parsial memiliki hubungan positif yang signifikan terhadap kepatuhan Wajib Pajak Orang Pribadi yang terdaftar di KPP Pratama Depok. Kemudian Khasanah (2014) dalam penelitiannya menunjukan bahwa pengetahuan perpajakan berpengaruh positif dan signifikan terhadap kepatuhan wajib pajak pada kantor wilayah direktorat jenderal pajak daerah istimewa Yogyakarta. Hal ini menunjukkan bahwa makin tinggi pengetahuan Wajib Pajak Orang Pribadi terhadap pemahaman pajak makin tinggi pula kepatuhan pajaknya. Oleh karena itu, hipotesis berikut dibuat untuk menentukan pengaruh pengetahuan perpajakan terhadap kepatuhan:

\section{H1:Pengetahuan berpengaruh positif terhadap perilaku kepatuhan wajib pajak.}

\section{Pengaruh Persepsi Keadilan Pajak dengan Kepatuhan Wajib Pajak}

Persepsi keadilan yang baik akan mendorong Wajib Pajak untuk patuh. 
Dimensi Keadilan Pajak merupakan salah satu variabel kunci yang mempengaruhi perilaku kepatuhan pajak (Jackson dan Milliron, 1986 dalam Basit, 2014). Pembayar pajak cenderung untuk menghindari membayar pajak jika mereka menganggap sistem pajak tidak adil. Hal tersebut menunjukkan pentingnya dimensi keadilan pajak sebagai variabel yang mempengaruhi perilaku kepatuhan pembayar pajak menurut Vogel, Spicer, dan Becker dalam Richardson yang dikutip oleh Pris (2010). Penelitian Fauzi et al (2017) menjelaskan bahwa keadilan prosedural mempengaruhi kepatuhan pajak. Oleh karena itu, hipotesis berikut dibuat untuk menentukan pengaruh persepsi keadilan pajak dengan kepatuhan wajib pajak:

$\begin{array}{ccr}\text { H2:Persepsi } & \text { keadilan } & \text { pajak } \\ \text { berpengaruh } & \text { positif } & \text { terhadap } \\ \text { Kepatuhan Wajib Pajak } & \end{array}$

\section{Pengaruh Pengetahuan Perpajakan terhadap Kepatuhan Wajib Pajak melalui Kepercayaan}

Pengetahuan merupakan faktor penting dalam meumbuhkan rasa percaya. Kepercayaan yang dimaksud dalam variabel ini adalah kepercayaan terhadap sistem hukum dan pemerintahan. Pengetahuan yang baik yang dimiliki wajib pajak mengenai sistem hukum dan pemerintahan yang ada pada saat ini akan menumbuhkan rasa kepercayaan wajin pajak terhadap sistem perpajakan. Semakin wajib pajak tahu bahwa pajak dialokasian dengan baik oleh pemerintah, semakin wajib pajak akan percaya. Kepercayaan wajib pajak akan meningkatkan kepatuhan wajib pajak, semakin tinggi tingkat kepercayaan wajib pajak maka akan semakin tinggi pula tingkat kepatuhannya. Penelitian Faizal at al (2017) juga menunjukkan bahwa kepercayaan pada otoritas pajak memiliki hubungan positif yang signifikan dengan kepatuhan perpajakan. Oleh karena itu, dibuatlah hipotesis sebagai berikut:

\section{H3:Pengetahuan perpajakan berpengaruh positif terhadap perilaku kepatuhan pajak melalui kepercayaan.}

\section{Pengaruh Persepsi Keadilan Pajak dengan Kepatuhan Wajib Pajak melalui kepercayaan}

Kepercayaan memiliki hubungan dengan persepsi keadilan, semakin baik persepsi keadilan Wajib Pajak maka akan semakin tinggi juga tingkat kepercayaan Wajib Pajak. Penelitian Faizal at al (2017) yang dilakukan di malaysia menunjukkan bahwa keadilan prosedural dapat mempengaruhi kepercayaan wajib pajak dengan hubungan signifikan positif. Jadi, ketika otoritas pajak memberikan pelayanan yang baik dan perlakuan yang adil kepada wajib pajak, ini mempengaruhi kepercayaan wajib pajak terhadap otoritas pajak. Kepercayaan wajib pajak akan meningkatkan kepatuhan wajib pajak, semakin tinggi tingkat kepercayaan wajib pajak maka akan semakin tinggi pula tingkat kepatuhannya. Penelitian Faizal at al (2017) juga menunjukkan bahwa kepercayaan pada otoritas pajak memiliki hubungan positif yang signifikan dengan kepatuhan perpajakan. Oleh karena itu, dibuatlah hipotesis sebagai berikut :

H4 : Persepsi keadilan pajak berpengaruh positif terhadap Kepatuhan Wajib Pajak melalui Kepercayaan.

\section{METODE PENELITIAN}

Penelitian ini merupakan penelitian survei yang termasuk dalam metode kuantitatif. Metode penelitian kuantitatif adalah metode penelitian yang digunakan untuk meneliti populasi atau sempel tertentu dengan tujuan untuk menguji hipotesis yang telah di tetapkan, metode ini berlandasan pada filsafat positivisme, menggunakan instrumen penelitian untuk pengumpulan data, dan analisis data bersifat kuantitatif/statistik (Sugiyono, 2016). Jenis data yang digunakan dalam 
penelitian ini adalah data kuantitatif. Data kuantitatif adalah data yang berbentuk angka atau data kualitatif yang diangkakan/scoring (Sugiyono, 2014). Sumber data yang digunakan dalam penelitian ini adalah data primer. Data primer yaitu data penelitian yang diperoleh secara langsung dari sumber asli atau pihak pertama. Data primer secara khusus dikumpulkan oleh peneliti untuk menjawab pertanyaan penelitian (Supriyono, 2017). Data primer dalam penelitian ini adalah data yang diperoleh dari hasil jawaban responden terhadap kuesioner yang dibagikan.

Dalam penelitian ini pengumpulan data yang dilakukan berdasarkan teknik kuesioner (angket). Daftar pertanyaan/pernyataan kuesioner dalam penelitian ini terdiri dari dua bagian. Pertama, bagian umum mengenai identitas responden yang terdiri dari 10 (sepuluh) buah pertanyaan yang meliputi nama, jabatan, jenis kelamin, pendidikan formal terakhir, usia, nama perusahaan, jenis usaha, tahun memulai usaha, kepemilikan NPWP (nomor pokok wajib pajak), dan tempat mendaftar NPWP. Kedua, berisi tentang pernyataan yang bersifat tertutup terdiri dari 38 (tiga puluh delapan) buah pernyataan yang berkaitan dengan variabel yang diteliti. Responden diminta untuk memilih jawaban dalan bentuk skala likert yang berisi lima tingkat jawaban dengan diberi skor sebagai berikut:

Skor $1=$ Sangat Tidak Setuju (STS)/Sangat Tidak Adil (STA)

Skor 2 = Tidak Setuju (TS)/Tidak Adil (TA)

Skor 3 = Ragu-ragu (R)

Skor $4=$ Setuju (S)/Adil (A)

Skor 5 = Sangat Setuju (SS)/Sangat Adil (SA).

Sebelum kuesioner penelitian mulai disebarkan kepada responden, kuesioner tersebut harus diuji kualitasnya terlebih dahulu. Hal ini perlu dilakukan karena benar tidaknya data sangat menentukan bermutu tidaknya hasil penelitian. Benar tidaknya data tergantung dari baik tidaknya instrumen penelitian yang digunakan. Instrumen yang baik harus memenuhi dua syarat yaitu valid dan reliabel. Dalam penelitian ini uji validitas butir instrumen dan reliabilitas dilakukan pada 52 responden di luar sampel yang sudah ditetapkan di atas, kemudian data yang terkumpul dianalisis menggunakan program SPSS. Kuesioner disebar sampai pernyataan dalam kuesioner valid dan reliabel, setelah beberapa kali melakukan penyebaran berikut adalah hasil dari kuesioner yang siap untuk di sebar.

Tabel 1 : Data Validitas Kuesioner

\begin{tabular}{|l|r|r|r|l|r|r|c|}
\hline \multicolumn{1}{|c|}{ Pernyataan } & r hitung & r tabel & \multicolumn{1}{c|}{ Ket } & Pernyataan & r hitung & r tabel & Ket \\
\hline \hline Pengetahuan1 & .639 & .273 & Valid & Keadilan 1 & .656 & .273 & Valid \\
\hline Pengetahuan2 & .391 & .273 & Valid & Keadilan 2 & .669 & .273 & Valid \\
\hline Pengetahuan3 & .601 & .273 & Valid & Keadilan 3 & .511 & .273 & Valid \\
\hline Pengetahuan4 & .581 & .273 & Valid & Keadilan 4 & .566 & .273 & Valid \\
\hline Pengetahuan5 & .581 & .273 & Valid & Keadilan 5 & .424 & .273 & Valid \\
\hline Pengetahuan6 & .520 & .273 & Valid & Keadilan 6 & .398 & .273 & Valid \\
\hline Pengetahuan7 & .666 & .273 & Valid & Keadilan 7 & .275 & .273 & Valid \\
\hline Pengetahuan8 & .606 & .273 & Valid & Keadilan 8 & .414 & .273 & Valid \\
\hline Pengetahuan9 & .453 & .273 & Valid & Keadilan 9 & .434 & .273 & Valid \\
\hline Pengetahuan10 & .704 & .273 & Valid & Keadilan 10 & .334 & .273 & Valid \\
\hline Pengetahuan11 & .649 & .273 & Valid & Keadilan 11 & .519 & .273 & Valid \\
\hline Kepercayaan 1 & .416 & .273 & Valid & Kepatuhan1 & .605 & .273 & Valid \\
\hline
\end{tabular}




\begin{tabular}{|l|l|l|l|l|r|r|c|}
\hline Kepercayaan 2 & .471 & .273 & Valid & Kepatuhan2 & .810 & .273 & Valid \\
\hline Kepercayaan 3 & .591 & .273 & Valid & Kepatuhan3 & .809 & .273 & Valid \\
\hline Kepercayaan 4 & .351 & .273 & Valid & Kepatuhan4 & .664 & .273 & Valid \\
\hline Kepercayaan 5 & .314 & .273 & Valid & Kepatuhan5 & .850 & .273 & Valid \\
\hline & & & & Kepatuhan6 & .771 & .273 & Valid \\
\hline & & & & Kepatuhan7 & .736 & .273 & Valid \\
\hline & & & & Kepatuhan8 & .887 & .273 & Valid \\
\hline & & & & Kepatuhan9 & .739 & .273 & Valid \\
\hline & & & & Kepatuhan10 & .892 & .273 & Valid \\
\hline & & & & Kepatuhan11 & .744 & .273 & Valid \\
\hline
\end{tabular}

Sumber: Data yang diolah (2018)

Tabel 2 : Data Reliabilitas Kuesioner

\begin{tabular}{|l|c|c|}
\hline \multicolumn{1}{|c|}{ Variabel } & Nilai Cronbanch's Alpha & Keterangan \\
\hline \hline Pengetahuan Perpajakan & .875 & reliabel \\
\hline Persepsi Keadilan & .811 & reliabel \\
\hline Kepercayaan & .676 & reliabel \\
\hline Kepatuhan & .950 & reliabel \\
\hline
\end{tabular}

Sumber: Data yang diolah (2018)

Penyebaran kuesioner dalam penelitian ini dilakukan dengan dua cara. Pertama, peneliti mengidentifikasi responden dengan mendatangi pasar-pasar, menelusuri jalan, dan mendatangi rumah para pelaku usaha (jika usahanya merupakan usaha rumahan) yang ada di Kabupaten Subang. Kedua, penyebaran kuesioner dilakukan secara online dengan bantuan layanan dari typeform. Setelah pertanyaan/pernyataan kuesioner diupload ke internet maka akan didapatkan URL kuesioner sebagai berikut: https://ari98.typeform.com/to/GScHR4.

Link tersebut kemudian disebarkan kepada para pemilik usaha via whatsapp, facebook, dan instagram.
Populasi dalam penelitian ini yaitu seluruh wajib pajak pengusaha yang termasuk kedalam PP 46 Tahun 2013 yang terdaftar di KPP Pratama Subang. Teknik pengambilan sampel yang digunakan dalam penelitian ini adalah convenience sampling yang termasuk kedalam nonprobability sampling. Convenience sampling yaitu teknik dalam memilih sampel, peneliti tidak mempunyai pertimbangan lain kecuali berdasarkan kemudahan saja (McCormack dan Hill, 1997). Penyebaran kuesioner dilakukan selama 26 hari. Berikut ini merupakan rincian dari kuesioner yang disebarkan:

Tabel 3 : Rincian Penyebaran Kuesioner

\begin{tabular}{lcccc}
\hline & $\begin{array}{c}\text { Kuesioner } \\
\text { Disebar }\end{array}$ & $\begin{array}{c}\text { Kuesioner } \\
\text { Kembali }\end{array}$ & $\begin{array}{c}\text { Kuesioner Tidak } \\
\text { Dapat Diolah }\end{array}$ & $\begin{array}{c}\text { Kuesioner } \\
\text { Diolah }\end{array}$ \\
\hline \hline Kuesioner Offline & 132 & 113 & 28 & 85 \\
Kuesioner Online & 40 & 21 & 6 & 15 \\
\hline Total & 172 & 134 & 34 & 100 \\
\hline
\end{tabular}

Sumber : Data diolah dari hasil penelitian (2018)

Berdasarkan hasil pada tabel 3, dapat ditentukan bahwa sampel (kuesioner yang dapat diolah) dalam penelitian ini adalah sebanyak 100 responden. 
Analisis dalam penelitian ini menggunakan metode Structural Equation Modeling (SEM) dengan software LISREL 8.80. Model persamaan struktural (structural equation modeling) adalah suatu teknik analisis multivariate generasi kedua yang menggabungkan antara analisis faktor dan analisis jalur sehingga memungkinkan peneliti untuk menguji dan mengestimasi secara simultan hubungan antara multiple exogenous dan endogenous variabel dengan banyak indikator (Chin, 1998; Gefen et al, 2000; Gefen et al, 2011; Kirby dan Bollen 2009; Pirouz, 2006 dalam Latan, 2012).

Menurut Ghozali dan Fuad (2014) terdapat asumsi-asumsi yang seharusnya dipenuhi dalam LISREL yaitu Normalitas dan Multikolinearitas. Penelitian ini telah memenuhi asumsi Multikolinearitas dalam artian data yang akan diolah dalam menetilian ini bebas dari multikolinearitas. Akan tetapi data dalam penelitian ini tidak normal maka dari itu peneliti menambahkan estimasi asymptotic covariance matrix. Hal tersebut akan mengakibatkan estimasi parameter beserta goodness of fit statisctic akan dianalisis berdasarkan pada keadaan data yang tidak normal (Ghozali dan Fuad, 2014).

Setelah memenuhi asumsi-asumsi dalam LISREL, selanjutnya terdapat beberapa tahap yang harus dilakukan ketika menggunakan Structural Equation Modelling. Menurut Bollen dan Long (1993) dalam Latan (2012), terdapat lima tahapan dalam SEM dimana setiap tahapan akan berpengaruh terhadap tahapan selanjutnya, yaitu (1) spesifikasi model, (2) identifikasi model, (3) estimasi model, (4) evaluasi model/uji kecocokan model, dan (5) respesifikasi model.

Tahap pertama, spesifikasi model berkaitan dengan pembentukan model awal persamaan struktural, sebelum dilakukan estimasi. Model SEM pada penelitian ini adalah sebagai berikut:

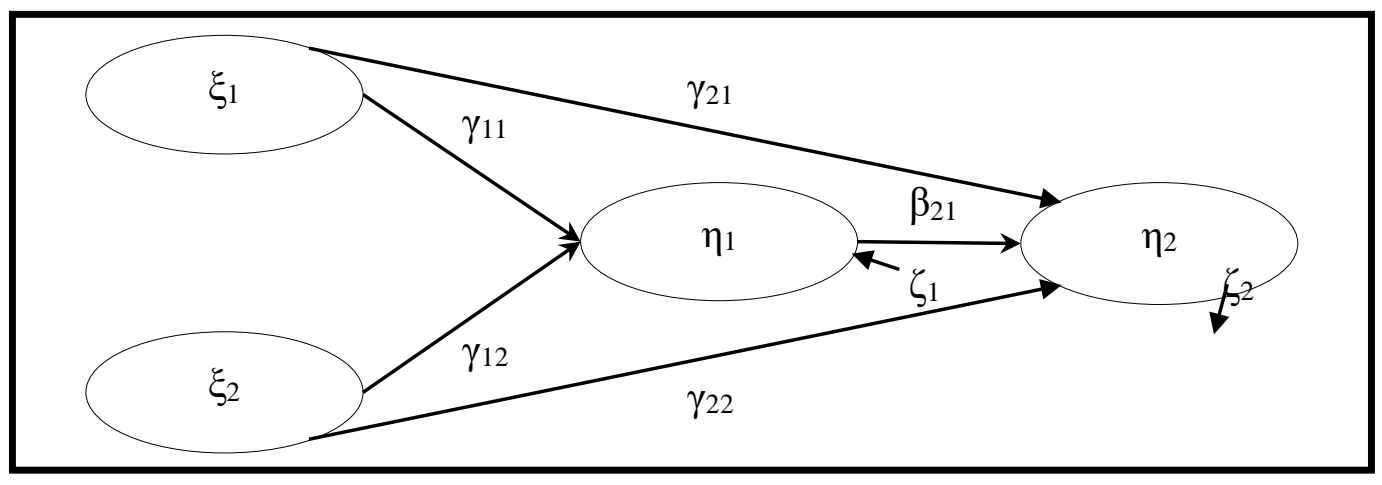

Gambar 1 : Model Struktural untuk Pengukuran Hipotesis

Sumber : Peneliti (2018)

Dimana:

$\xi_{1}=$ Pengetahuan Perpajakan (TXKNOW)

$\xi_{2}=$ Persepsi Keadilan (PEROFAIR)

$\eta_{1}=$ Kepercayaan (TRUST)

$\eta_{2}=$ Kepatuhan Wajib Pajak (TXCOM)

Pengetahuan pajak ialah setiap informasi seputar perpajakan yang harus diketahui dan digunakan oleh wajib pajak sebagai dasar dalam pengambilan keputusan dan menentukan perilaku dalam hal pelaksanaan hak dan kewajiban perpajakannya. Setiap wajib pajak harus memiliki pengetahuan mengenai ketentuan 
umum dan tata cara perpajakan, sistem perpajakan, dan fungsi pajak (Siti Kurnia Rahayu (2010) dalam Khasanah, 2014). Indikator dari variabel ini berdasarkan penelitian Khasanah (2014) yaitu pengetahuan mengenai ketentuan umum dan tata cara perpajakan, pengetahuan mengenai fungsi perpajakan, dan pengetahuan mengenai sistem perpajakan di indonesia.

Keadilan pajak adalah perlakuan yang tidak sewenangwenang, tidak berat sebelah, atau tidak memihak yang diberlakukan untuk wajib pajak atas sistem perpajakan yang berlaku, dan persepsi keadilan pajak adalah penilaian wajib pajak terhadap keadilan pajak tersebut. Menurut Giligan dan Richardson (2005), keadilan pajak terdiri dari lima dimensi keadilan yaitu keadilan umum, timbal balik dengan pemerintah, kepentingan pribadi, ketentuan khusus, dan struktur tarif pajak.

Kepercayaan yang dimaksud dalam variabel ini adalah kepercayaan terhadap sistem hukum dan pemerintahan yang berarti keyakinan yang ada pada setiap wajib pajak terhadap sistem perpajakan yang dijalankan oleh pemerintah. Kepercayaan terhadap sistem pemerintahan yaitu kepercayaan terhadap sistem hukum, kepercayaan terhadap politisi dan kepercayaan terhadap pemungutan pajak (Purnamasari, 2016 dalam Juwanti, 2017). Indikator dari variabel ini berdasarkan penelitian Juwanti (2017) adalah kepercayaan pada pemerintah, kepercayaan pada sistem hukum, kepercayaan pada lembaga peradilan, kepercayaan kepada pemungutan pajak yang dialokasikan kembali ke rakyat, dan kepercayaan terhadap petugas pemungut pajak (fiskus).

$$
\text { Kepatuhan wajib pajak }
$$

didefinisikan sebagai perilaku wajib pajak yang merujuk pada tingkat ketaatannya dalam menunaikan kewajiban perpajakan, baik dalam perhitungan, penyetoran, maupun pelaporan pajak terutang
(Fatmawati, 2015). Indikator dari variabel ini berdasarkan penelitian Fatmawati (2015) yaitu pendaftaran NPWP, penghitungan pajak terutang, pembayaran pajak, dan pelaporan SPT.

Tahap kedua, setelah model berhasil dispesifikasikan dilakukan identifikasi model. Dalam Structural Equation Modeling, diharapkan memperoleh model yang over-identified (degree of freedom positif) dan dihindari adanya model yang under-identified (degree of freedom negatif) (Kasanah, 2015). Dari hasil keluaran LISREL didapatkan degree of freedom sebesar 659 , sehingga model pada penelitian ini teridentifikasi sebagai over identified model.

Tahap ketiga, yaitu estimasi model, tahap ini dilakukan untuk memperoleh nilai dari parameter-parameter yang ada didalam model. Dalam penelitian ini data tidak berdistribusi normal secara univariate dan multivariate sehingga, untuk mengatasi data penelitian yang tidak normal peneliti memilih untuk menambahkan estimasi asymptotic covariance matrix. Model akhir dalam penelitian ini adalah model-2.

Tahap selanjutnya adalah uji kecocokan model, setelah model penelitian yang baik ditemukan dalam penelitian ini yaitu model-2, tahap selanjutnya yaitu menguji kecocokan model. Pengujian ini dilakukan untuk menghindari model dari loading factor yang buruk dan membangun konstruk yang valid agar didapatkan analisis model srtuktural yang baik (Alzahrini, 2011 dalam Rasyid, 2013). Setelah dilakukan uji kecocokan, model-2 ini memiliki nilai yang fit sehingga model-2 dapat diterima.

Tahap terakhir adalah respesifikasi model. Setelah didapatkan model akhir yang fit yakni model-2 penelitian. Hasil pengujian kecocokan model-2 penelitian menunjukkan bahwa model tersebut telah memenuhi kriteria baik, sehingga tidak perlu dilakukan respesifikasi model. 


\section{HASIL PENELITIAN DAN PEMBAHASAN}

Sampel data yang diperoleh memiliki beberapa karakteristik berdasarkan jenis kelamin, pendidikan terakhir, usia, jenis usaha, dan tahun mulai usaha, sebagaimana disajikan pada tabel 4.3 .

Tabel 4 : Karakteristik Responden

\begin{tabular}{llcc}
\hline \multicolumn{1}{c}{ Klasifikasi / Karakteristik } & N $=\mathbf{1 0 0}$ & Persentase \\
\hline Jenis Kelamin & Laki-laki & 65 & $65 \%$ \\
& Perempuan & 35 & $35 \%$ \\
\hline Pendidikan Terakhir & SMA dan Sederajat & 57 & $57 \%$ \\
& Diploma 3 & 2 & $2 \%$ \\
& Sarjana (S1) & 26 & $26 \%$ \\
& Master (S2) & 2 & $2 \%$ \\
& Lainnya : & & \\
& - SD & 7 & $7 \%$ \\
& - SMP & 4 & $4 \%$ \\
& - D1 & 1 & $1 \%$ \\
& - Tidak Sekolah & 1 & $1 \%$ \\
\hline Usia & Dibawah 20 tahun & 0 & - \\
& $21-30$ tahun & 36 & $36 \%$ \\
& $31-40$ tahun & 25 & $25 \%$ \\
& $41-50$ tahun & 27 & $27 \%$ \\
& Diatas 50 tahun & 12 & $12 \%$ \\
\hline Jenis Usaha & Usaha Perdagangan & 58 & $58 \%$ \\
& Usaha Pertanian & 5 & $5 \%$ \\
& Usaha Industri & 18 & $18 \%$ \\
& Usaha Jasa & 19 & $19 \%$ \\
\hline Tahun Mulai Usaha & $1955-1985$ & 7 & $7 \%$ \\
& $1989-1995$ & 12 & $12 \%$ \\
& $1996-2005$ & 29 & $29 \%$ \\
& 2006-2017 & 52 & $52 \%$ \\
\hline
\end{tabular}

Sumber : Data diolah dari hasil penelitian (2018)

Selanjutnya uji dilakukan terhadap setiap konstruk melalui evaluasi terhadap validitas konstruk dan evaluasi terhadap reliabilitas konstruk. Uji validitas dilakukan dengan melihat nilai $\mathrm{t}$ muatan faktornya dan muatan faktor standarnya.
Suatu variabel memiliki validitas yang baik jika $t$ muatan faktornya $>1,96$ dan muatan faktor standarnya $>0,3$. Hasil uji validitas dan reliabilitas dapat dilihat pada Tabel 5 dan Tabel 6.

Tabel 5 : Hasil Uji Kecocokan Model-2 Pengukuran Variabel Teramati Eksogen

\begin{tabular}{|l|l|l|l|}
\hline \multirow{2}{*}{$\begin{array}{c}\text { Variabel Teramati } \\
\text { (Eksogen) }\end{array}$} & \multicolumn{2}{|c|}{ Parameter Pengukuran } & \multirow{2}{*}{$\begin{array}{c}\text { Kesimpulan } \\
\text { Validitas }\end{array}$} \\
\cline { 2 - 3 } SK1 & SLF & Nilai t & Baik \\
\hline TK2 & 0,54 & 9,54 & Baik \\
\hline
\end{tabular}




\begin{tabular}{|c|c|c|c|}
\hline \multirow{2}{*}{$\begin{array}{l}\text { Variabel Teramati } \\
\text { (Eksogen) }\end{array}$} & \multicolumn{2}{|c|}{ Parameter Pengukuran } & \multirow{2}{*}{$\begin{array}{c}\text { Kesimpulan } \\
\text { Validitas }\end{array}$} \\
\hline & SLF & Nilai t & \\
\hline TK3 & 0,53 & 10,04 & Baik \\
\hline TK4 & 0,55 & 7,83 & Baik \\
\hline TK5 & 0,52 & 8,52 & Baik \\
\hline TK6 & 0,36 & 3,89 & Baik \\
\hline TK7 & 0,42 & 5,87 & Baik \\
\hline TK8 & 0,47 & 6,74 & Baik \\
\hline TK9 & 0,46 & 7,65 & Baik \\
\hline TK10 & 0,53 & 11,09 & Baik \\
\hline TK11 & 0,30 & 3,57 & Baik \\
\hline POF1 & 0,47 & 8,43 & Baik \\
\hline POF2 & 0,50 & 10,25 & Baik \\
\hline POF4 & 0,46 & 8,35 & Baik \\
\hline POF5 & 0,32 & 3,57 & Baik \\
\hline POF6 & 0,50 & 9,50 & Baik \\
\hline POF7 & 0,35 & 5,54 & Baik \\
\hline POF8 & 0,49 & 8,97 & Baik \\
\hline POF9 & 0,35 & 5,33 & Baik \\
\hline POF11 & 0,34 & 5,22 & Baik \\
\hline
\end{tabular}

Sumber : Data diolah dari hasil penelitian (2018)

Tabel 6 : Hasil Uji Kecocokan Model- 2 Pengukuran Variabel Teramati Endogen

\begin{tabular}{|c|c|c|c|}
\hline \multirow{2}{*}{$\begin{array}{l}\text { Variabel Teramati } \\
\text { (Endogen) }\end{array}$} & \multicolumn{2}{|c|}{ Parameter Pengukuran } & \multirow{2}{*}{$\begin{array}{c}\text { Kesimpulan } \\
\text { Validitas }\end{array}$} \\
\hline & SLF & Nilai t & \\
\hline TR1 & 0,57 & $*$ & Baik \\
\hline TR2 & 0,56 & 8,86 & Baik \\
\hline TR3 & 0,47 & 5,99 & Baik \\
\hline TR5 & 0,48 & 7,06 & Baik \\
\hline TC1 & 0,49 & $*$ & Baik \\
\hline TC2 & 0,50 & 7,31 & Baik \\
\hline TC3 & 0,46 & 3,54 & Baik \\
\hline TC4 & 0,43 & 5,31 & Baik \\
\hline TC5 & 0,63 & 6,22 & Baik \\
\hline TC6 & 0,50 & 3,68 & Baik \\
\hline TC7 & 0,58 & 5,81 & Baik \\
\hline TC8 & 0,63 & 6,51 & Baik \\
\hline TC9 & 0,63 & 6,80 & Baik \\
\hline TC10 & 0,64 & 6,92 & Baik \\
\hline TC11 & 0,64 & 6,74 & Baik \\
\hline
\end{tabular}

Sumber : Data diolah dari hasil penelitian (2018)

Keterangan : *= ditetapkan secara default oleh LISREL, nilai t tidak diestimasi. (Wijayanto, 2008 dalam Rasyid, 2013) melakukan pengukuran reliabilitas. Dalam penelitian ini reliabilitas data diukur dari

Setelah pengukuran validitas dilakukan, langkah berikutnya adalah 46 nilai Composite Reliability (CR). Berikut adalah hasil pengukuran reliabilitas: 
Tabel 7 : Nilai CR Hasil Perhitungan

\begin{tabular}{|c|c|c|c|}
\hline \multirow{2}{*}{$\begin{array}{c}\text { Variabel } \\
\text { Laten } \\
\end{array}$} & \multicolumn{2}{|c|}{ Parameter Pengukuran } & \multirow{2}{*}{$\begin{array}{c}\text { Kesimpulan } \\
\text { Reliabilitas }\end{array}$} \\
\hline & $\mathbf{C R}$ & Nilai CR Rekomendasi & \\
\hline TK & 0,75 & $\mathrm{CR}=0,60$ & Baik \\
\hline POF & 0,67 & $\mathrm{CR}=0,60$ & Baik \\
\hline TR & 0,60 & $\mathrm{CR}=0,60$ & Baik \\
\hline TC & 0,83 & $\mathrm{CR}=0,60$ & Baik \\
\hline
\end{tabular}

Sumber : Data diolah dari hasil penelitian (2018)

Hasil analisis deskriptif pada setiap variabel penelitian dapat dilihat pada tabel 8 .

Tabel 8 : Hasil Deskriptif Statistik

\begin{tabular}{|l|r|r|r|r|}
\hline & Pengetahuan & $\begin{array}{c}\text { Persepsi } \\
\text { keadilan }\end{array}$ & \multicolumn{1}{c|}{ Kepercayaan } & \multicolumn{1}{c|}{ Kepatuhan } \\
\hline Mean & 3.8809 & 3.1882 & 3.4300 & 3.8227 \\
\hline Median & 3.8636 & 3.1818 & 3.4000 & 4.0000 \\
\hline Std. Deviation & .44097 & .43306 & .57516 & .48076 \\
\hline Minimum & 2.55 & 2.18 & 1.60 & 2.27 \\
\hline Maximum & 5.00 & 4.73 & 5.00 & 5.00 \\
\hline
\end{tabular}

Sumber : Data diolah dari hasil penelitian (2018)

Dalam penelitian ini terdapat 4 langsung. Untuk hasil dari pengujian buah hipotesis yang terdiri dari 2 buah masing-masing hipotesis dapat dilihat pada hipotesis dengan hubungan langsung dan 2 tabel 8 dan gambar 2.

buah hipotesis dengan hubungan tidak

Tabel 8 : Efek Dekomposisi Variabel Laten Penelitian

\begin{tabular}{|c|c|c|c|c|}
\hline & \multicolumn{2}{|c|}{$\begin{array}{c}\text { Pengaruh Tidak } \\
\text { Langsung }\end{array}$} & \multicolumn{2}{|c|}{ Pengaruh Total } \\
\hline & Nilai t & Signifikansi & Nilai $t$ & Signifikansi \\
\hline \multicolumn{5}{|c|}{ Pengaruh Terhadap TR } \\
\hline TK & - & - & 0,99 & Tdk Signifikan \\
\hline POF & - & - & 4,42 & Signifikan \\
\hline \multicolumn{5}{|c|}{ Pengaruh Terhadap TC } \\
\hline TK & 0,34 & Tdk Signifikan & 2,38 & Signifikan \\
\hline $\mathrm{POF}$ & 0,39 & Tdk Signifikan & 2,69 & Signifikan \\
\hline TR & - & - & 0,38 & Tdk Signifikan \\
\hline
\end{tabular}

Sumber : Data diolah dari hasil penelitian (2018) 


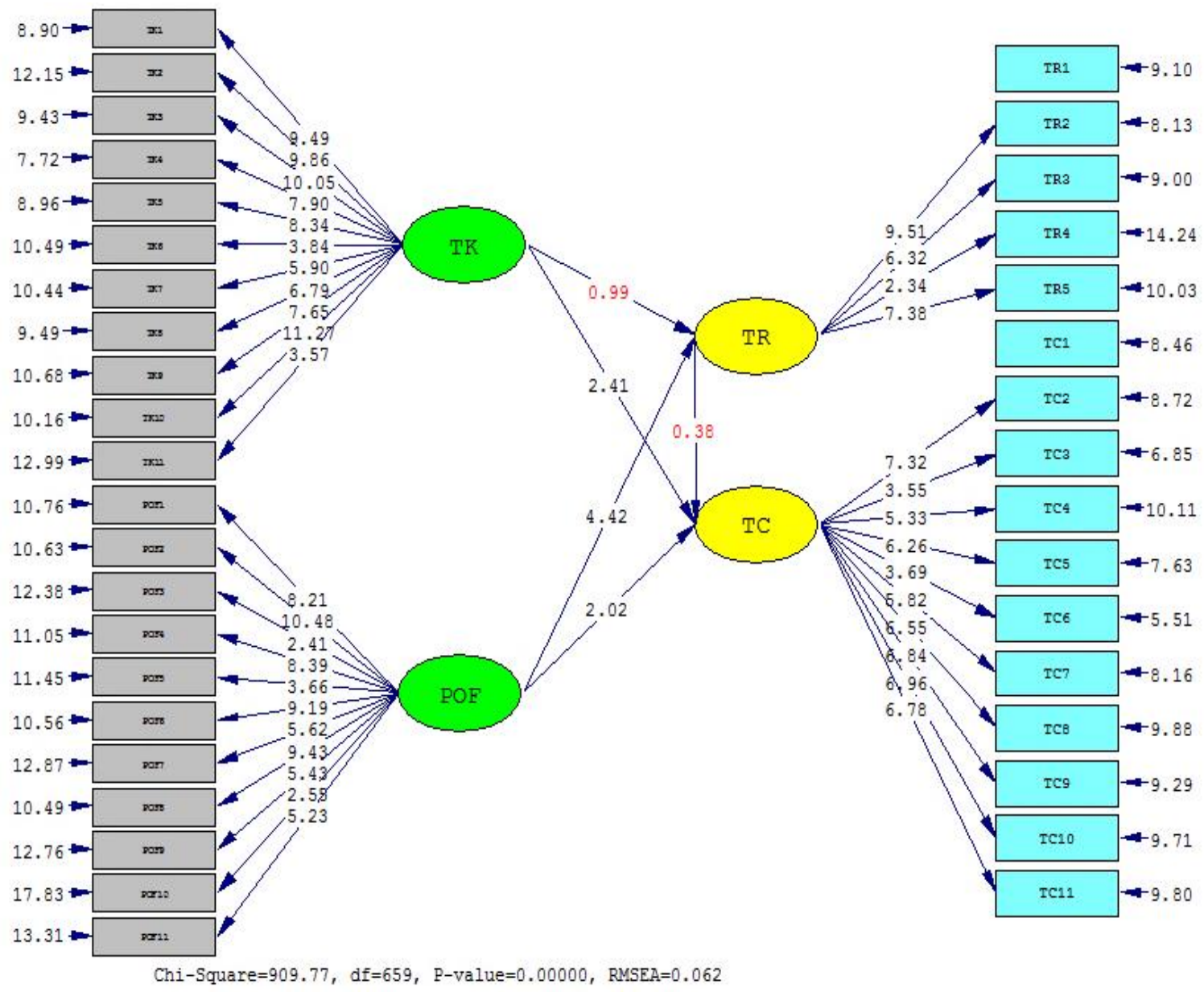

Gambar 2 : Path Diagram T-value

Sumber : Data diolah dari hasil penelitian (2018)

Hipotesis 1 : Pengetahuan perpajakan berpengaruh positif terhadap perilaku kepatuhan wajib pajak.

Hasil pengujian terhadap hipotesis 1 , yang terdapat pada gambar 2 dan tabel 8 menunjukan bahwa hubungan antara konstruk TK dan TC (pengetahuan dan kepatuhan) memiliki nilai t sebesar 2,41 (t $>1,96$ ) dan $\mathrm{t}$ total 2,38 ( $\mathrm{t}$ total > 1,96). Dengan demikian dapat disimpulkan bahwa TK (pengetahuan pajak) berpengaruh positif dan signifikan terhadap TC (kepatuhan wajib pajak), sehingga Hipotesis 1 diterima.

Hasil pengujian hipotesis pertama dapat diartikan bahwa pengetahuan pajak adalah variabel yang mempengaruhi kepatuhan wajib pajak, hal ini menunjukan bahwa semakin tinggi pengetahuan pajak, maka semakin tinggi pula kepatuhan wajib pajak, begitu juga sebaliknya, jika semakin rendah pengetahuan pajak maka semakin rendah pula kepatuhan pajaknya.

Hasil ini sejalan dengan penelitian terdahulu Saridane (2012) dan Khasanah (2014) bahwa pengetahuan perpajakan berpengaruh positif signifikan terhadap kepatuhan wajib pajak. Oleh karena itu, agar pengetahuan pajak meningkat maka sebaiknya pendidikan tentang pajak dilakukan diusia dini, selain itu sosialisasi tentang pajak oleh pemerintah perlu ditingkatkan agar para wajib pajak lebih paham dan pengetahuan pajaknya meningkat, sehingga kepatuhan wajib pajak akan meningkat dan penerimaan pajak dapat mencapai targetnya. 


\section{Hipotesis 2 : Persepsi keadilan pajak berpengaruh positif terhadap kepatuhan wajib pajak.}

Hasil pengujian terhadap hipotesis 2, yang terdapat pada gambar 2 dan tabel 8 menunjukan bahwa hubungan antara konstruk POF dan TC (persepsi keadilan dan kepatuhan) memiliki nilai $\mathrm{t}$ sebesar 2,02 ( $\mathrm{t}>1,96)$ dan $\mathrm{t}$ tabel 2,69 ( $\mathrm{t}$ total > 1,96). Dengan demikian dapat disimpulkan bahwa POF (persepsi keadilan) berpengaruh positif dan signifikan terhadap TC (kepatuhan wajib pajak), sehingga Hipotesis 2 diterima.

Hasil pengujian hipotesis kedua dapat diartikan bahwa persepsi keadilan pajak adalah variabel yang mempengaruhi kepatuhan wajib pajak, hal ini menunjukan bahwa semakin tinggi persepsi wajib pajak mengenai keadilan pajak, maka semakin tinggi pula kepatuhan wajib pajak, begitu juga sebaliknya, jika wajib pajak merasa ada ketidakadilan dalam pajak maka semakin rendah kepatuhan pajaknya.

Hasil ini semakin mempertegas hasil hipotesa pada penelitian terdahulu Dharmawan (2013) dan Nurhayani et al (2014) bahwa persepsi keadilan berpengaruh signifikan terhadap kepatuhan wajib pajak. Oleh karena itu, pemerintah harus berlaku adil terhadap setiap wajib pajak, menentukan peraturan-peraturan yang sesuai dengan keadaan wajib pajak, memberikan pelayanan yang sama bagi setiap wajib pajak, dan jika terjadi pelanggaran baik yang dilakukan oleh wajib pajak maupun pemerintah harus dikenakan sanksi yang adil dan sama sesuai peraturan perpajakan yang berlaku.

\section{Hipotesis 3 : Pengetahuan perpajakan berpengaruh positif terhadap perilaku kepatuhan pajak melalui kepercayaan.}

Hasil pengujian terhadap hipotesis 3, yang terdapat pada tabel 8 menunjukan pengaruh tidak langsung dari variabel pengetahuan perpajakan (TK) terhadap kepatuhan wajib pajak (TC) melalui kepercayaan (TR) memiliki nilai t sebesar $0,34$ ( $\mathrm{t}<1,96)$. Dengan demikian dapat disimpulkan bahwa kepercayaan (TR) tidak memediasi hubungan antara pengetahuan perpajakan (TK) dan kepatuhan wajib pajak (TC) atau dapat dikatakan bahwa TK tidak berpengaruh terhadap TC melalui variabel TR, sehingga Hipotesis 3 ditolak.

Hasil pengujian hipotesis ketiga dapat diartikan bahwa kepercayaan terhadap sistem hukum dan pemerintah tidak memediasi pengeruh pengetahuan terhadap kepatuhan, hal ini terjadi karena kepercayaan wajib pajak dari hasil survey rendah, wajib pajak tidak percaya terhadap pemerintah dikarenakan banyaknya kasuskasus penggelapan uang yang dilakukan oleh oknum pemerintah.

Oleh karena itu, pemerintah harus lebih memperbanyak sosialisasi kepada masyarakat khususnya wajib pajak, disamping sosialisasi tentang peraturan perpajakan pemerintah juga diharapkan dapat menjelaskan kepada wajib pajak mengenai penerimaan pajak dan digunakan untuk apa uang pajak selama ini. Pemerintah harus lebih transparan terhadap masyarakat agar masyarakat khususnya wajib pajak percaya, sehingga dapat meningkatkan kepatuhan wajib pajak.

Pengetahuan mengenai peraturan perpajakan memang penting, ketika wajib pajak memiliki pengetahuan itu mereka akan membayar pajak, akan tetapi mereka hanya sebatas patuh akan peraturan dan itu membuat masih adanya wajib pajak yang akan mencoba mengecilkan pajaknya asalkan masih sesuai aturan. Maka dari itu pengetahuan mengenai penerimaan dan kegunaan uang pajak sangat penting, hal ini akan meningkatkan rasa percaya wajib pajak dan membuat wajib pajak lebih bertanggungjawab atas kewajibannya dalam perpajakan. 


\section{Hipotesis 4 : Persepsi keadilan pajak berpengaruh positif terhadap kepatuhan wajib pajak melalui kepercayaan.}

Hasil pengujian terhadap hipotesis 4, yang terdapat pada tabel 8 menunjukan pengaruh tidak langsung dari variabel persepsi keadilan (POF) terhadap kepatuhan wajib pajak (TC) melalui kepercayaan (TR) memiliki nilai t sebesar $0,39$ ( $\mathrm{t}<1,96)$. Dengan demikian dapat disimpulkan bahwa kepercayaan (TR) tidak memediasi hubungan antara persepsi keadilan (POF) dan kepatuhan wajib pajak (TC) atau dapat dikatakan bahwa POF tidak berpengaruh terhadap TC melalui variabel TR, sehingga Hipotesis 4 ditolak.

Hasil pengujian hipotesis keempat dapat diartikan bahwa kepercayaan terhadap sistem hukum dan pemerintah tidak memediasi pengeruh persepsi keadilan terhadap kepatuhan, hasil ini sejalan dengan penelitian terdahulu Faizal et al (2017) yang menunjukkan bahwa kepercayaan tidak memediasi hubungan antara keadilan dan kepatuhan. Meskipun dalam penelitian ini persepsi keadilan berpengaruh terhadap kepercayaan (lihat tabel 4.18), yang artinya semakin tinggi persepsi keadilan makan semakin tinggi pula kepercayaan. Akan tetapi kepercayaan tidak berpengaruh terhadap kepatuhan, hal ini terjadi karena kepercayaan wajib pajak dari hasil survey rendah.

Oleh karena itu, pemerintah harus lebih memperbanyak sosialisasi kepada masyarakat khususnya wajib pajak untuk lebih meyakinkan mereka agar lebih bertanggungjawab akan pajak, tentunya pemerintah harus lebih transparan terhadap masyarakat agar masyarakat khususnya wajib pajak percaya, sehingga dapat meningkatkan kepatuhan wajib pajak.

Model akhir penelitian yang dihasilkan pada penelitian ini yang dianggap sebagai model kepatuhan wajib pajak adalah terlihat pada gambar 3 .

\section{SIMPULAN, KETERBATASAN, DAN SARAN}

\section{Simpulan}

Pengetahuan perpajakan secara langsung berpengaruh positif dan signifikan terhadap kepatuhan wajib pajak PP 46 Tahun 2013 yang terdaftar di KPP Pratama Subang. Dengan demikian dapat diartikan bahwa pengetahuan pajak adalah variabel yang mempengaruhi kepatuhan wajib pajak, hal ini menunjukan bahwa semakin tinggi pengetahuan pajak, maka semakin tinggi pula kepatuhan wajib pajak, begitu juga sebaliknya, jika semakin rendah pengetahuan pajak maka semakin rendah pula kepatuhan pajaknya.

Persepsi keadilan secara langsung berpengaruh positif dan signifikan terhadap kepatuhan wajib pajak PP 46 Tahun 2013 yang terdaftar di KPP Pratama Subang. Dengan demikian dapat diartikan bahwa semakin tinggi persepsi wajib pajak mengenai keadilan pajak, maka semakin tinggi pula kepatuhan wajib pajak, begitu juga sebaliknya, jika wajib pajak merasa ada ketidakadilan dalam pajak maka semakin rendah kepatuhan pajaknya. 


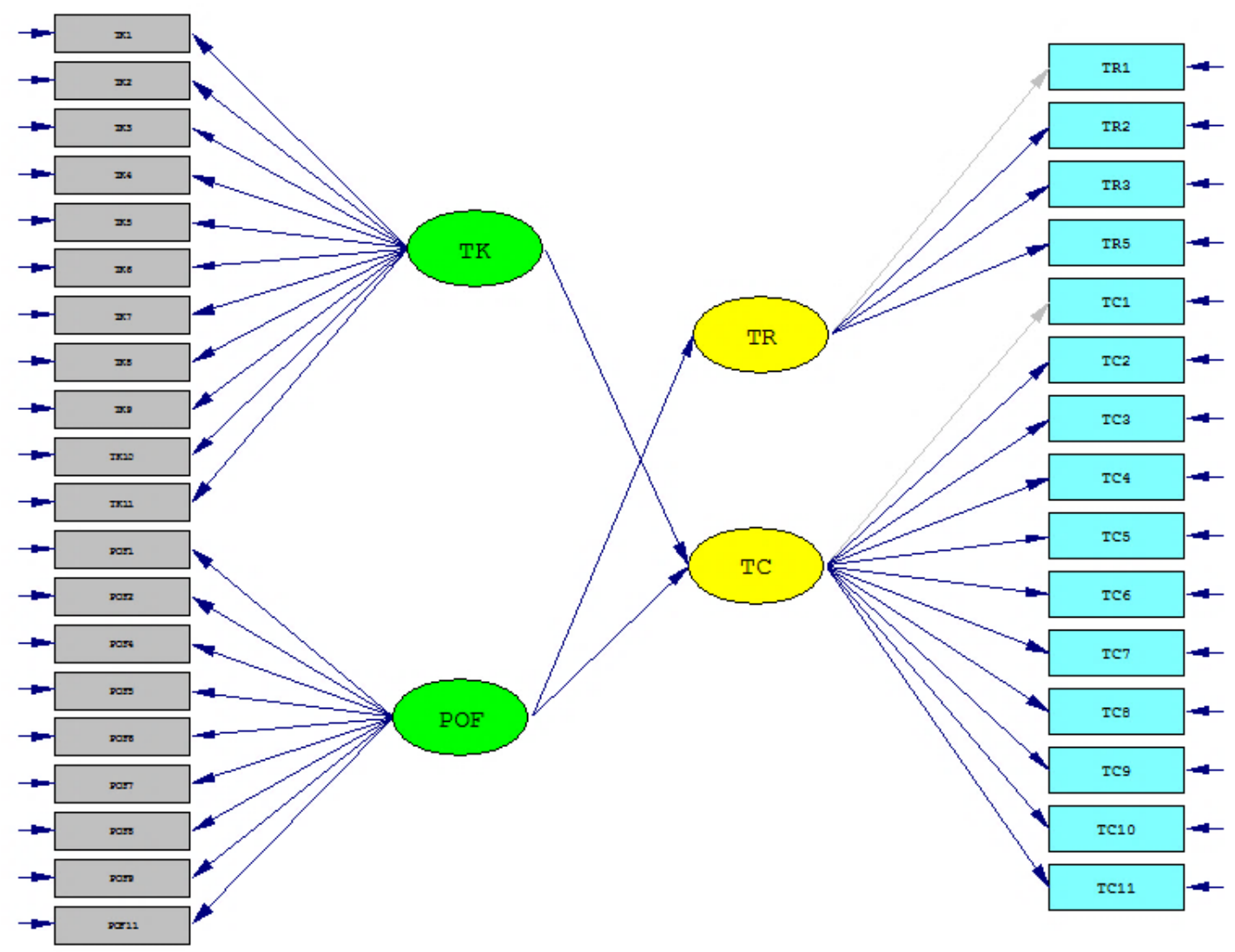

\section{Gambar 3 : Model Akhir Penelitian Kepatuhan Wajib Pajak (Model-2)}

Sumber : Data diolah dari hasil penelitian (2018)

Pengetahuan perpajakan tidak berpengaruh terhadap kepatuhan wajib pajak melalui kepercayaan. Hal ini terjadi karena kepercayaan wajib pajak dari hasil survey rendah, wajib pajak tidak percaya terhadap pemerintah dikarenakan banyaknya kasus-kasus penggelapan uang yang dilakukan oleh oknum pemerintah.

Persepsi keadilan tidak berpengaruh terhadap kepatuhan wajib pajak melalui kepercayaan. Hal ini terjadi karena kepercayaan wajib pajak dari hasil survey rendah, wajib pajak tidak percaya terhadap pemerintah dikarenakan banyaknya kasus-kasus penggelapan uang yang dilakukan oleh oknum pemerintah.

\section{Keterbatasan Penelitian}

Adapun keterbatasan penelitian ini adalah (1) penelitian ini hanya menggunakan instrumen kuesioner sehingga belum menggambarkan secara utuh kondisi yang terjadi pada objek penelitian. (2) penelitian ini memakai jumlah responden minimal dikarenakan susahnya mencari responden yang dibutuhkan karena data wajib pajak adalah privasi bagi kantor pajak. (3) penelitian ini hanya meneliti tingkat kepatuhan wajib pajak PP 46 tahun 2013, sehingga hasil analisis yang diperoleh hanya berlaku untuk wajib pajak PP 46 tahun 2013, tidak termasuk wajib pajak orang pribadi, badan dan pengusaha kena pajak (PKP).

\section{Saran}

Adapun saran yang dapat peneliti berikan berkaitan dengan penelitian ini adalah sebagai berikut :

1. Bagi Pemerintah

Untuk lebih meningkatkan
penyuluhan atau pelatihan 
mengenai akuntansi dan perpajakan.

b. Untuk lebih meningkatkan sosialisasi dalam menyebarkan peraturan-peraturan perpajakan terbaru yang meliputi tata cara penghitungan dan pelaporan pajak terutang, tarif pajak yang berlaku, sanksi atau denda yang berlaku agar masyarakat atau wajib pajak dapat mengetahui dan memahami peraturan-peraturan perpajakan yang berlaku.

2. Bagi Wajib Pajak

a. Pajak merupakan sumber pendapatan negara terbesar dalam menopang pembangunan maka sudah seharusnya kita patuh dalam memenuhi kewajiban perpajakan.

b. Para wajib pajak disarankan untuk lebih memperluas pengetahuannya tentang peraturan perpajakan agar dapat lebih patuh dalam memenuhi kewajiban perpajakannya di kemudian hari. Hal ini dapat dilakukan dengan cara wajib pajak aktif mengikuti peraturan perpajakan yang terbaru.

3. Bagi Peneliti Selanjutnya

a. Peneliti yang tertarik untuk melakukan kajian di bidang yang sama dapat menggunakan variabelvariabel yang tidak digunakan dalam penelitian ini, atau menambah variabel bebas.

b. Penelitian selanjutnya hendaknya menambah indikator (jumlah item pertanyaan) untuk setiap variabel penelitian, agar hasil penelitian lebih baik lagi.

c. Untuk memperbanyak jumlah responden dan juga memperluas ruang lingkup penelitian, hal ini agar dapat memperoleh jawaban dan hasil penelitian yang sesuai.

d. Sebaiknya untuk penelitian selanjutnya akan lebih baik jika dilengkapi dengan wawancara ataupun pernyataan tertulis sehingga dapat menggali semua hal yang menjadi tujuan penelitian dan penggantian teknik pengambilan sampel penelitian.

e. Peneliti yang tertarik untuk melakukan kajian dibidang yang sama dapat mempertimbangkan dan memanfaatkan perubahan tarif PP 46 Tahun 2013.

\section{DAFTAR PUSTAKA}

Basit, Abdul. 2014. Pengaruh Persepsi Kontrol Perilaku, Pengetahuan Pajak Dan Persepsi Keadilan Pajak Terhadap Kepatuhan Wajib Pajak. Jurnal TEKUN/Volume V, No. 01, 23- 48.

Faizal, Sellywati Mohd, Mohd Rizal Palil, Ruhanita Maelah dan Rosiati Ramli. 2017. Perception of justice, trust and tax compliance behavior in Malaysia. Kasetsart Journal of Social Sciences 38 (2017) 226-232.

Fatmawati. 2015. Pengaruh Pemahaman Wajib Pajak Atas Pp No. 46 Tahun 2013 Dan Implementasi Self Assessment System Terhadap Kepatuhan Wajib Pajak Dengan Persepsi Wajib Pajak Sebagai Variabel Moderasi (Studi Empiris Pada Pelaku UMKM Kerajinan Gerabah Kasongan). Skripsi Program Studi Akuntansi Jurusan Pendidikan Akuntansi Fakultas Ekonomi Universitas Negeri Yogyakarta.

Ghozali, Imam dan Fuad. 2014. Structural Equation Modeling Teori, Konsep dan Aplikasi Dengan Program LISREL 9.10. Badan Penerbit UNDIP.

Giligan, George dan Grant Richardson. 2005. Perceptions of Tax Fairness and Tax Compliance in Australia and Hongkong - A Preliminary Study. Journal of Financial Crime Vol. 12 No. 4. 
http://stiesa.ac.id/main/index.php/82berita-kampus/225-perpajakanuntuk-pelaku-umkm-di-subangbersama-kpp-pratama-subang (Diakses pada tanggal 16 Desember 2017 ; 07:41 AM)

http://www.pajak.go.id/content/article/paja k-sebagai-ujung-tombakpembangunan (Diakses pada tanggal 16 Desember $2017 ; 8: 06$ AM)

http://www.pajak.go.id/content/article/men akar-kadar-kepatuhan-wajib-pajak (Diakses pada tanggal 19 Januari 2018 ; 10:31 PM)

http://www.pajak.go.id/content/article/mer awat-potensi-pajak-sektor-umkmmelalui-kehumasan-0 (Diakses pada tanggal 19 Januari 2018; 11.00 PM)

http://www.pajak.go.id/content/belajarpajak (Diakses pada tanggal 21 Januari $2018 ; 12: 22$ AM)

http://www.pajak.go.id/content/22113penghasilan-yang-dikenakan-pphfinal (Diakses pada tanggal 21 Januari 2018 ; 12:22 AM)

http://finansial.bisnis.com/read/20180130/ 10/732093/penerimaan-pajak-dariumkm-dinilai-tepat (Diakses pada tanggal 28 Februari $2018 ; 05: 14$ PM)

Imaniati, Zaen Zulha. 2016. Pengaruh Persepsi Wajib Pajak Tentang Penerapan Pp No. 46 Tahun 2013, Pemahaman Perpajakan, Dan Sanksi Perpajakan Terhadap Kepatuhan Wajib Pajak Usaha Mikro, Kecil, Dan Menengah Di Kota Yogyakarta Jurnal Nominal Volume V Nomor 2 ; Akuntansi Universitas Negeri Yogyakarta.

Juwanti, Febriani Ramadhani. 2017. Pengaruh Pengetahuan Perpajakan, Kesadaran Wajib Pajak, Norma Sosial, Kepercayaan Pada Pemerintah Dan Sanksi
Pajak Terhadap Kepatuhan Wajib Pajak Dalam Melakukan Pembayaran Pajak Bumi Dan Bangunan (Studi Pada Wajib Pajak Bumi Dan Bangunan Kecamatan Colomadu Kabupaten Karanganyar). Skripsi Fakultas Ekonomi Dan Bisnis Islam Institut Agama Islam Negeri Surakarta.

Kasanah, Aprilia. 2015. Penggunaan Metode Structural Equation Modeling Untuk Analisis Faktor Yang Mempengaruhi Kualitas Pelayanan Perpustakaan Dengan Program Lisrel 8.80. Skripsi Jurusan Matematika Fakultas Matematika Dan Ilmu Pengetahuan Alam Universitas Negeri Semarang.

Khasanah, Septiyani Nur. 2014. Pengaruh Pengetahuan Perpajakan, Modernisasi Sistem Administrasi Perpajakan, Dan Kesadaran Wajib Pajak Terhadap Kepatuhan Wajib Pajak Pada Kantor Wilayah Direktorat Jenderal Pajak Daerah Istimewa Yogyakarta Tahun 2013. Skripsi Program Studi Akuntansi Jurusan Pendidikan Akuntansi Fakultas Ekonomi Universitas Negeri Yogyakarta.

Latan, Hengky. 2012. Structural Equation Modeling Konsep dan Aplikasi Menggunakan Program Lisrel 8.80. Bandung : Alfabeta

McCormack, Brenda dan Elizabeth Hill. 1997. Conducting a Survey the SPSS Workbook. International Thomson Bussines Press.

Nugroho, Edwin. 2016. Faktor-Faktor Yang Mempengaruhi Kemauan Membayar Pajak Wajib Pajak Orang Pribadi Yang Melakukan Pekerjaan Bebas Di Kpp Pratama Yogyakarta. Skripsi Program Studi Akuntansi Fakultas Ekonomi Universitas Negeri Yogyakarta. 
PP Nomor 46 Tahun 2013 "Pajak penghasilan atas penghasilan dari usaha yang diterima atau diperoleh wajib pajak yang memiliki peredaran bruto tertentu".

Pris K. Andarini. 2010. Dampak Dimensi Keadilan Pajak Terhadap Tingkat Kepatuhan Wajib Pajak Badan Andarini. Skripsi Fakultas Ekonomi Universitas Diponegoro Semarang.

Prof. Dr. Sugiyono. 2014. Metode Penelitian Kuantitatif, Kualitatif, dan $R \& D$. Bandung : Alfabeta.

Prof. Dr. Sugiyono. 2016. Metode Penelitian Kuantitatif, Kualitatif, dan $R \& D$. Bandung : Alfabeta.

R.A. Supriyono. 2017. Akuntansi Keperilakuan. Yogyakarta : Grasindo.

Rasyid, Hainur. 2013. Analisis Faktorfaktor yang Mempengaruhi Kesuksesan Implementasi EGovernment Studi Kasus Sistem Informasi dan Komputerisasi Haji Terpadu. Fakultas Ilmu Komputer Jakarta Universitas Indonesia.

Robbins, Stephen P. dan Timothy A Judge. 2008. Perilaku Organisasi Buku 1 Edisi 12. Jakarta : Salemba Empat.

Russell, Jesse dan Ronald Cohn. 2012. Theory Of Planned Behavior. Book on Demand.

Saad, Natrah. 2012. Tax Non-Compliance Behaviour: Taxpayers View. Elsevier Ltd : Procedia - Social and Behavioral Sciences.

Saridane, Poetrie Aliza. 2012. Pengaruh Pengetahuan Perpajakan Dan
Persepsi Keadilan Perpajakan Terhadap Tingkat Kepatuhan Wajib Pajak Orang Pribadi Yang Terdaftar Di Kpp Pratama Depok. Universitas Gundatama.

Sudrajat, Ajat dan Arles Parulian Ompusunggu. 2015. Pemanfaatan Teknologi Informasi, Sosialisasi Pajak, Pengetahuan Perpajakan, dan Kepatuhan Pajak. Jurnal Riset Akuntansi dan Perpajakan JRAP Vol. 2, No. 2, Desember 2015, hal 193 - 202 ISSN 2339 - 1545.

Wahyu, Haris Triono. 2016. Pengaruh Dimensi Keadilan, Pengetahuan Pajak, Sanksi Pajak, Moral Wajib Pajak Dan Komunikasi Setelah Pemberlakuan Pp No. 46 Terhadap Tingkat Kepatuhan Wajib Pajak Umkm (Studi Empiris Pada Wajib Pajak Pelaku UMKM yang Terdaftar di KPP Pratama Karanganyar. Skripsi Program Studi Akuntansi Fakultas Ekonomi Dan Bisnis Universitas Muhammadiyah Surakarta.

Zahra, Inna Nafitasari. 2017. Pengauh Persepsi Atas Efektifitas Sistem Perpajakan dan Pengetahuan Pajak Terhadap Kepatuhan Wajib Pajak Dengan Kesadaran Membayar Pajak Sebagai Variabel Intervening (Studi Pada WPOP Yang Terdaftar Di KPP Pratama Surakarta). Skripsi Jurusan Akuntansi Syariah Fakultas Ekonomi dan Bisnis Islam Institut Agama Islam Negeri Surakarta. 